\title{
The Evaluation of Genetic Profiles of UGT1A4 and UGT1A6 in the Turkish Population
}

\section{Türk Popülasyonunda UGT1A4 ve UGT1A6 Genetik Profillerinin Değerlendirilmesi}

\author{
@ZZuhal Uçkun Şahinoğulları' \\ 'Mersin University, Faculty of Pharmacy, Department of Pharmaceutical Toxicology, Yenisehir, Mersin, Turkey
}

\begin{abstract}
Aim: Uridine diphosphate glucuronosyltransferases (UGTs) are a superfamily of conjugation phase II enzymes and is responsible for catalyzing the glucuronidation of many endobiotic or xenobiotic substrates. The present study aimed to determine allele and genotype frequencies of UGT1A4 c.142T >G, UGT1A6 c.541A >G and UGT1A6 c. 19T $>$ G polymorphisms in the healthy Turkish population and also to compare them with different population data.

Material and Method: UGT1A4 c.142T>G, UGT1A6 c.541A>G and c.19T>G polymorphisms were determined in DNA samples of 114 healthy Turkish volunteers using polymerase chain reaction and restriction fragment length polymorphism methods.

Results: The frequencies of variant alleles were $12.7 \%$ for UGT1A4 c. $142 T>G, 39.9 \%$ for UGT1A6 c.541A $>G$ and $44.7 \%$ for UGT1A6 c.19T>G. The frequencies of the UGT1A4 and UGT1A6 variant alleles determined were observed to be similar to those of the majority of European populations. However, the UGT1A6 frequencies in the Turkish population differed significantly from those reported specifically for the Thai and East Asian populations.

Conclusion: This study introduces the frequencies of UGT1A4 and UGT1A6 polymorphisms in the Turkish population. As a result of our literature reviews, this study is the first report that investigated the frequencies of UGT1A6 c.541A $>\mathrm{G}$ and c.19T>G polymorphisms in the healthy Turkish population. A study of the UGTA1A4*3 polymorphism was found in Turkish epilepsy patients in the literature search, but not in healthy individuals. Therefore, it can be stated that this study is also the first report investigating the UGT1A4*3 polymorphism in the healthy Turkish individuals. This study could ensure clinically beneficial information about drug metabolism by UGT1A4 and UGT1A6 in the Turkish population.
\end{abstract}

Keywords: UGT1A4, UGT1A6, glucuronidation, polymorphism, Turkish population
Öz

Amaç: Üridin difosfat glukuronosiltransferazlar (UGT'ler), konjugasyon faz II enzimlerinin bir süper ailesidir ve birçok endobiyotik veya ksenobiyotik substratın glukuronidasyonunu katalize etmekten sorumludur. Bu çalışmada, sağlıklı Türk popülasyonunda UGT1A4 c. 142T>G, UGT1A6 c.541A>G ve UGT1A6 c.19T>G polimorfizmlerinin allel ve genotip frekanslarının belirlenmesi ve farklı popülasyon verileriyle karşılaştırılması amaçlanmıştır.

Gereç ve Yöntem: UGT1A4 c.142T>G, UGT1A6 c.541A>G ve c.19T>G polimorfizmleri, polimeraz zincir reaksiyonu ve restriksiyon fragman uzunluğu polimorfizmi yöntemleri kullanılarak 114 sağlıklı Türk gönüllülerinin DNA örneklerinde belirlendi.

Bulgular: Varyant allel frekansları UGT1A4 c.142T>G için \% 12.7 , UGT1A6 c.541A>G için \% 39.9 ve UGT1A6 c.19T>G için \% 44.7 idi. Belirlenen UGT1A4 ve UGT1A6 varyant allel frekanslarının, Avrupa popülasyonlarının çoğunluğuna benzer olduğu gözlendi. Ancak, Türk popülasyonundaki UGT1A6 frekanslarının, özellikle Tayland ve Doğu Asya popülasyonlarının frekanslarından önemli ölçüde farklıydı.

Sonuç: Bu çalışma, Türk popülasyonunda UGT1A4 ve UGT1A6 polimorfizmlerinin sıklığını sunmaktadır. Literatür incelemelerimizin sonucu olarak, bu çalışma sağlıklı Türk popülasyonunda UGT1A6 c.541A>G ve c.19T>G polimorfizmlerinin sıklığını araştıran ilk rapordur. Literatür taramasında Türk epilepsi hastalarında UGT1A4*3 polimorfizmi ile ilgili bir çalışma bulunmuştur, ancak sağlıklı bireyler ile ilgili veri bulunmamıştır. Dolayısıyla bu çalışmanın, sağlıklı Türk bireylerinde UGT1A4*3 polimorfizmini araştıran ilk rapor olduğu ifade edilebilir. Bu çalışma, Türk popülasyonunda UGT1A4 ve UGT1A6 ile gerçekleşen ilaç metabolizması hakkında klinik olarak faydalı bilgiler sağlayabilir.

Anahtar Kelimeler: UGT1A4, UGT1A6, glukuronidasyon, polimorfizm, Türk popülasyonu

Corresponding (IIletişim): Zuhal Uçkun Şahinoğulları, Department of Pharmaceutical Toxicology, Faculty of Pharmacy, Mersin University, Mersin, Turkey

E-mail (E-posta): uckunzuhal@mersin.edu.tr

Received (Geliş Tarihi): 05.12.2020 Accepted (Kabul Tarihi): 11.02.2021 


\section{INTRODUCTION}

Glucuronidation is one of the most important phase II metabolic pathways in human. It is catalyzed by the family of UDPglucuronosyl transferase (UGTs) enzymes which are a superfamily of membrane attached proteins in the endoplasmic reticulum. [1] UGTs (EC 2.4.1.17) catalyze the conjugation of endobiotic or xenobiotic compounds with glucuronic acid from the cofactor UDP-a-D-glucuronic acid (UDPGA). ${ }^{[2]}$ Glucuronidation is responsible for about about 40 to $70 \%$ of xenobiotic elimination $^{[3]}$ and commonly makes compounds biologically inactive and increases excretion of compounds through urine or bile. ${ }^{[2]}$ Some of the UGT substrates are bile acids, bilirubin, thyroid hormones, fatty acids, environmental toxins and pollutants, dietary components, tobacco smoke carcinogens, and various prescribed medications including acetaminophen, morphine, tamoxifen, mycophenolic acid, ciprofibrate, SN-38, aromatase inhibitors (letrozole, exemestane and anastrozole), vorinostat, steroid hormones, lamotrigine, some tricyclic antidepressants, and antipsychotics such as olanzapine and clozapine. ${ }^{[4-6]}$ UGTs are expressed in various tissues and organs, primarily in the liver as well as in lungs, placenta, uterus, brain and intestinal mucosa. ${ }^{[6]}$

The superfamily of UGT consist of four families; which are UGT1, UGT2, UGT3 and UGT8. ${ }^{[7]}$ The enzymes UGT1 and UGT2 have significant roles in toxicology and pharmacology, but the contribution of the UGT3 and UGT8 enzymes to drug metabolism has been determined to be relatively small. ${ }^{[7]}$ The UGT1A gene is located on chromosome 2 q37 and encodes nine functional proteins (UGT1A4 and UGT1A3-1A10), which are produced by the splicing of a unique first exon to the common exons $2-5 .{ }^{[8]}$

Many variants have been identified in the superfamily of UGT. ${ }^{[9]}$ Genetic polymorphisms in genes encoding UGT enzymes have toxicological, physiological and pharmacological significance. [10] In the UGT1A4 gene, more than 100 single nucleotide polymorphisms (SNPs) have been identified, and one of the best studied allele among them was UGT1A4*3 which encodes a Leu48Val amino acid change (L48V; c.142T>G; rs2011425) in the corresponding enzyme. ${ }^{[6]}$ The UGT1A4*3 was associated with twice as high much glucuronidation activity in vitro. ${ }^{[1]}$ Furthermore, L48V was suggested to associated with lower mean plasma concentrations of olanzapine in patients with schizophrenia. ${ }^{[5,12]}$ Alterations in glucuronidation activities due to UGT1A4 alleles have been reported to be substrate-dependent. ${ }^{[9]}$

In the UGT1A6 gene, the three most common nonsynonymous polymorphisms were Thr181Ala (541 A>G), Arg184Ser (552 A>C) and Ser7Ala (19 T>G). ${ }^{[13]}$ Both Thr181Ala and Arg184Ser variants are mostly (>98\%) in complete linkage disequilibrium ${ }^{[14]}$ These two variants result in a $30-50 \%$ decline in enzyme activity as opposed to the wild type allele. ${ }^{[14,15]}$ It has been suggested that UGT1A6 polymorphism affect the glucuronidation rate of its substrates in in vitro studies, and also that the A541G, A552C and T19G SNPs in the coding sequence of UGT1A6 gene may affect the pharmacokinetics of valproic acid, by that means, changing the adverse effect profiles and efficacy of the drug. ${ }^{[16]}$ Alterations in the enzyme function of UGTs may influence the clearance of and thus, systemic exposure to their substrates. ${ }^{[17]}$
The frequencies of the SNPs of UGT1A4 and UGT1A6 included in the study may vary among diverse populations. Differences in the frequencies of these SNPs can cause individual and ethnic differences in glucuronidation capacity, leading to differences in drug response, drug efficacy, toxicity of drugs and other xenobiotics, predisposition to various diseases.

A study of the UGTA1A4*3 polymorphism in the Turkish population was found in the literature survey. Gulcebi et al. ${ }^{[10]}$ investigated the relationship between UGT1A4*2 and UGT1A4*3 polymorphisms and lamotrigine serum concentration in epilepsy patients. On the other hand, in the Turkish population, no studies of the polymorphism mentioned in UGT1A4 gene in healthy individuals and data on the polymorphisms commonly found in UGT1A6 gene were found. Therefore, the aim of this study is to determine allele and genotype frequencies of UGT1A4*3 and UGT1A6 A541G and UGT1A6T19G polymorphisms in the healthy Turkish population and also to compare them with different population data.

\section{MATERIAL AND METHOD Samples}

The DNA samples extracted in the previous study (22/10/2015, protocol no: 2015/317) were included in the present survey. Additionally, the ethical approval of the current study was also obtained from Mersin University Ethics Committee (08/07/2020, protocol no: 2020/490). The genomic DNA samples isolated from whole blood were stored at $-80^{\circ} \mathrm{C}$ until analysis. This study was carried out using DNA samples of 114 healthy, unrelated Turkish volunteers aged 18-65 and was conducted according to the Good Clinical Practices and the Declaration of Helsinki.

\section{Genotyping}

UGT1A4 c.142T>G, UGT1A6 c.541A>G and c.19T>G SNPs were analyzed using polymerase chain reaction $(P C R)$ and restriction fragment length polymorphism (RFLP) methods. PCR-RFLP methods were carried out in a MiniAmp Plus Thermal Cycler (Thermo Fisher, USA).

\section{UGT1A4 C. 142 T>G, p.L48V, rs2011425}

UGT1A4 c.142T>G SNP was identified according to Hakooz et al. ${ }^{[9]}$ with slight modifications. The forward (F): 5'-GCCCATAACGAAAGGCAGT-3' and reverse (R): 5'-CACACAACACCTATGAAGGG-3' primers were used to amplify 567 bp of the UGT1A4 gene that contain the polymorphic region. $\mathrm{PCR}$ products were digested at $37^{\circ} \mathrm{C}$ for 15 minutes using Fast Digest Stul restriction enzyme (Thermo Fisher Scientific). The genotypes of the wild type (319, $248 \mathrm{bp})$, mutant (567 bp) and heterozygous (567, 319 and $248 \mathrm{bp}$ ) were determined using $2 \%$ agarose gel with ethidium bromide (Figure 1A).

\section{UGT1A6 c.541A>G, p.T181A, rs2070959}

Analysis of the UGT1A6 c.541A >G SNP was performed using primers set; F: 5'-GGAAATACCTAGGAGCCCT GTGA-3' and R: 5'-AGGAGCCAAATGAGTGAGGGAG-3!.[13] The primers were used to amplify the $992 \mathrm{bp}$ fragment of the gene. PCR products were digested at $37^{\circ} \mathrm{C}$ for 15 minutes using Fast Digest Nsil restriction enzyme (Thermo Fisher Scientific). The genotypes of the wild 
type (992 bp), mutant (616 and 376 bp) and heterozygous (992, 616 and $376 \mathrm{bp}$ ) were identified using $2 \%$ agarose gel with ethidium bromide (Figure 1B).

\section{UGT1A6 c.19T>G, p.Ser7Ala, rs6759892}

The 19T>G polymorphism in the UGT1A6 gene was analysed using primer set; F: 5'-GATTTGGAGAGTGAAAACTCTTT-3' and R: 5'-CAGGCACCACCACTACAATCTC-3'!13] The primers were used to amplify the $237 \mathrm{bp}$ fragment of the gene. PCR products were digested in 15 minutes at $37^{\circ} \mathrm{C}$ using Fast Digest Hhal restriction enzyme (Thermo Fisher Scientific). The genotypes of the wild type (237 bp), mutant (165 and $72 \mathrm{bp}$ ) and heterozygous (237, 165 and $72 \mathrm{bp}$ ) were detected using $2.5 \%$ agarose gel with ethidium bromide (Figure 1C).

For each SNP analysis, $10 \%$ of the samples were randomly reanalyzed for quality assurance, which ensured 100\% concordance.

\section{Statistical analysis}

Genotype and allele frequencies were calculated by genotype counting method. The observed frequencies of UGT1A4 and UGT1A6 SNPs were compared with the expected frequencies using the chi-square $\left(X^{2}\right)$ test based on HardyWeinberg equilibrium. The obtained data of the present study were compared with previously reported data of various populations. Differences in the frequencies between populations were tested by $X^{2}$ test. Statistical analyzes were conducted with IBM SPSS 25.0 computer software for Windows. $p<0.05,<0.01$ and $<0.001$ were accepted statistically significant.

\section{RESULTS}

UGT1A4 c.142T>G, UGT1A6 c.541A>G and c.19T>G SNPs were detected with DNA samples of 114 healthy Turkish individuals using the PCR-RFLP methods. Of the 114 individuals included in the study, 52 (46\%) were male, 62 (54\%) were female. The mean age with standard deviation of the study population was $28.55 \pm 9.33$ years ( $26.15 \pm 8.50$ years for female and $31.42 \pm 9.55$ years for male).

As shown in Table 1, distributions of the genotypes frequencies obtained were consistent with Hardy-Weinberg equilibrium. The frequencies of TT, TG and GG genotypes of UGT1A4 polymorphism were $75.4 \%, 23.7 \%$ and $0.9 \%$, respectively, and thus, the frequencies of $\mathrm{T}$ and $\mathrm{G}$ alleles were identified as $87.3 \%$ and $12.7 \%$, respectively. The frequencies of $A A, A G$ and $G G$ genotypes of UGT1A6 A541G SNP were $33.3 \%, 53.5 \%$ and $13.2 \%$, respectively, and the frequencies of $A$ and $G$ alleles were found as $60.1 \%$ and $39.9 \%$. The frequencies of TT, TG and GG genotypes of UGT1A6T19G SNP were $27.2 \%, 56.1 \%$ and $16.7 \%$, respectively, and therefore, the frequencies of $\mathrm{T}$ and $\mathrm{G}$ alleles were detected as $52.3 \%$ and $44.7 \%$, respectively.

Figure 1 shows agarose gel images of RFLPs of UGT1A4 c. $142 \mathrm{~T}>\mathrm{G}$, UGT1A6 c.541A>G and c.19T>G SNPs determined by electrophoresis.

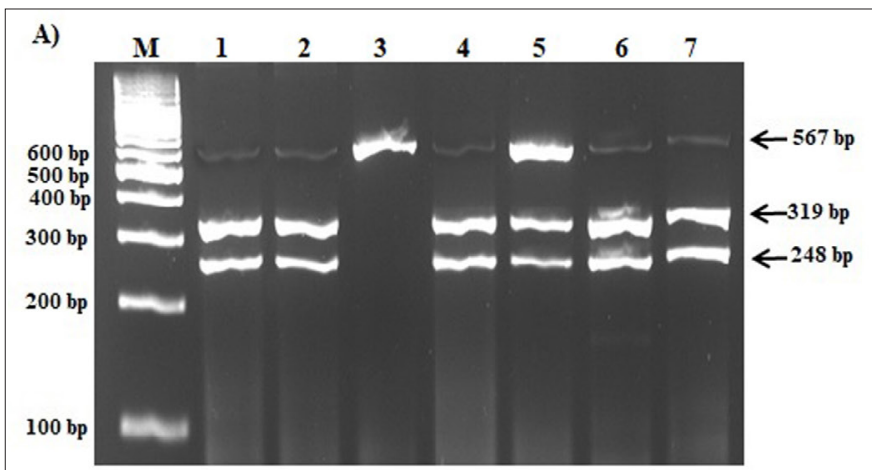

B)

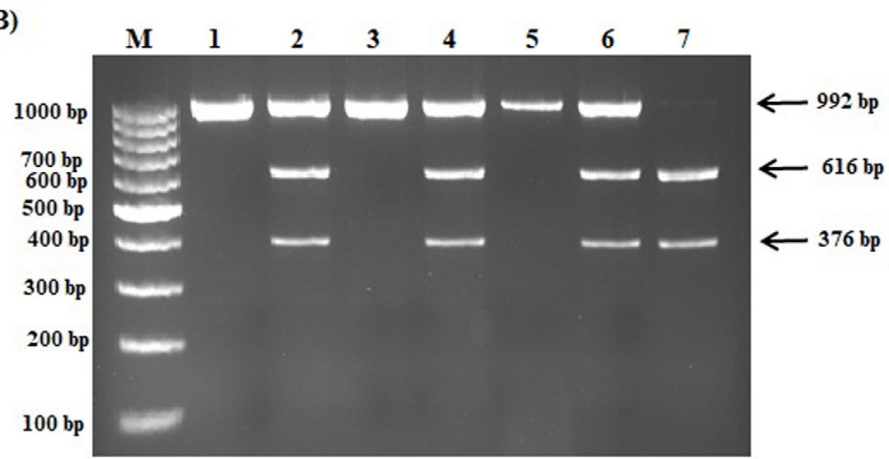

C)

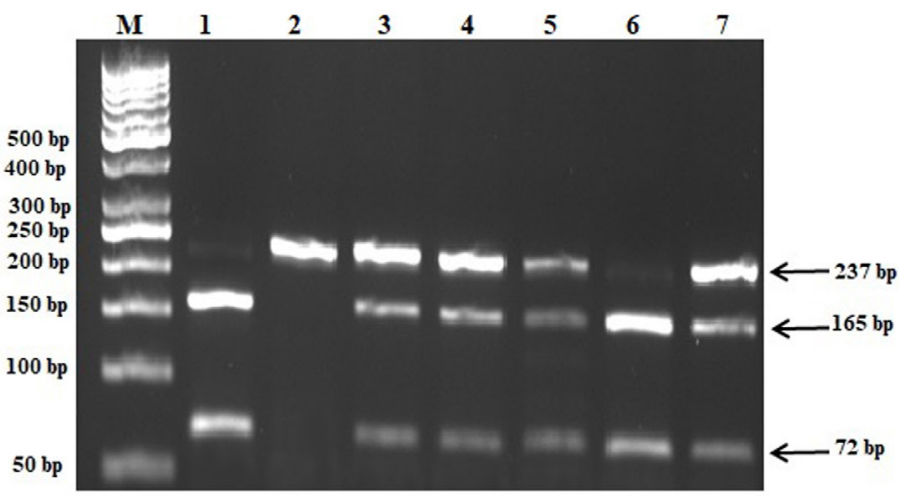

Figure 1. Agarose gel images of restriction fragment length polymorphisms of UGT1A4T142G, UGT1A6 A541G and UGT1A6T19G single nucleotide polymorphisms (SNPs) determined by electrophoresis. For UGT1A4T142G SNP (A part); M: Marker (100 bp), Lane 1, 2, 4, 6 and 7: wild type genotype (319, 248 bp), Lane 3: mutant genotype (567 bp), Lane 5: heterozygous genotype (567, 319, 248 bp). For UGT1A6 A541G SNP (B part); M: Marker (100 bp), Lane 1, 3 and 5: wild type genotype (992 bp), Lane 2, 4 and 6: heterozygous genotype (992, 616, 376 bp), Lane 7: mutant genotype (616, 376 bp). For UGT1A6 T19G SNP (C part); M: Marker (50 bp), Lane 2: wild type genotype (237 bp), Lane 3-5 and 7: heterozygous genotype (237, 165, 72 bp), Lane 1 and 6: mutant genotype (165, 72 bp). 


\begin{tabular}{|c|c|c|c|c|c|}
\hline Variants & Genotype & Observed genotype frequency, n (\%) & Expected genotype frequency, $n$ & HWE & Allele frequency, n (\%) \\
\hline \multicolumn{6}{|l|}{ UGT1A4*3 } \\
\hline $\begin{array}{l}\text { c. } 142 T>G \\
\text { rs2011425 }\end{array}$ & $\begin{array}{l}\text { TT } \\
\text { TG } \\
\text { GG }\end{array}$ & $\begin{array}{c}86(75.4) \\
27(23.7) \\
1(0.9)\end{array}$ & $\begin{array}{c}86.8 \\
25.3 \\
1.8\end{array}$ & $\begin{array}{l}X^{2}=0.507 \\
p=0.476\end{array}$ & $\begin{array}{r}\mathrm{T}=199(87.3) \\
\mathrm{G}=29(12.7)\end{array}$ \\
\hline \multicolumn{6}{|l|}{ UGT1A6 } \\
\hline $\begin{array}{l}\text { c. } 541 A>G \\
\text { rs2070959 }\end{array}$ & $\begin{array}{l}\text { AA } \\
\text { AG } \\
\text { GG }\end{array}$ & $\begin{array}{l}38(33.3) \\
61(53.5) \\
15(13.2)\end{array}$ & $\begin{array}{l}41.2 \\
54.7 \\
18.2\end{array}$ & $\begin{array}{l}X^{2}=1.523 \\
p=0.217\end{array}$ & $\begin{array}{c}A=137(60.1) \\
G=91(39.9)\end{array}$ \\
\hline $\begin{array}{l}\text { c. } 19 T>G \\
\text { rs6759892 }\end{array}$ & $\begin{array}{l}\text { TT } \\
\text { TG } \\
\text { GG }\end{array}$ & $\begin{array}{l}31(27.2) \\
64(56.1) \\
19(16.7)\end{array}$ & $\begin{array}{l}34.8 \\
56.4 \\
22.8\end{array}$ & $\begin{array}{l}X^{2}=2.089 \\
p=0.148\end{array}$ & $\begin{array}{l}\mathrm{T}=126(52.3) \\
\mathrm{G}=102(44.7)\end{array}$ \\
\hline
\end{tabular}

\section{DISCUSSION}

To our knowledge, this is the first report that investigated the allele and genotype frequencies of UGT1A6 c.541A $>G$ and c.19T>G in a healthy Turkish population. A study of the UGTA1A4*3 polymorphism in the Turkish population was found in the literature survey. However, the study conducted by Gulcebi et al. ${ }^{[10]}$ on the UGTA1A4*3 polymorphism was conducted in epilepsy patients in the Turkish population, not healthy individuals. Therefore, it can be stated that this study is the first report investigating the UGT1A4*3 polymorphism in the healthy Turkish individuals. The frequency found by Gulcebi et al. ${ }^{[10]}$ was similar to the frequency of UGT1A4*3 polymorphism observed in healthy individuals in the present study.

Table 2 shows a comparison of the frequencies UGT1A4 c. $142 T>G, U G T 1 A 6$ c.541 A $>$ G and c.19T>G SNPs (\%) observed in this study with those of other populations ${ }^{[10,12,17,19-28]}$ and the 1000 Genomes Project. ${ }^{[18]}$

The variant frequencies of UGT1A4 c.142T>G of the present study were similar to White ancestry, including Swedish, Utah Residents with Northern and Western European Ancestry (CEU), Finnish in Finland (FIN), British in England and Scotland (GBR), Iberian populations in Spain (IBS), Toscani in Italy (TSI), Colombian in Medellin, Colombia (CLM), Mexican Ancestry in Los Angeles, California (MXL), Peruvian in Lima, Peru (PEL), Puerto Rican in Puerto Rico (PUR). The frequencies of the variant allele in White ancestry were between $6.1 \%$ and $15.9 \%$. Also, the frequency of UGT1A4 c.142T>G was not different from frequencies previously found in East Asian populations, including Japanese, Korean, Chinese, Han Chinese, Japanese in Tokyo, Japan (JPT), Han Chinese in Bejing, China (CHB) but was found statistically significant lower than that in Kinh in Ho Chi Minh City, Vietnam (KHV). Among South Asian populations, no significant difference was observed between the frequency in Turkish and those in Gujarati Indian in Houston, Texas (GIH) and Punjabi in Lahore, Pakistan (PJL) populations; however, statistically significant difference was found between the study's findings and those in Sri Lankan Tamil in the UK (STU) and Indian Telugu in the UK (ITU) populations. There was no significant distinction between Turkish and Black ancestry, including Esan in Nigeria (ESN), Luhya in Webuye, Kenya
(LWK), African Caribbeans in Barbados (ACB) and African ancestry in SW USA (ASW) in terms of UGT1A4 T142G SNP. The frequencies of the variant allele in Black ancestry were between 8.1 and $10.1 \%$.

The UGT1A6 c.541A $>\mathrm{G}$ allele frequency differences between Turkish and White ancestry that include GBR, IBS, CLM, MXL, PEL, PUR were considered to be statistically significant; however, it was not statistically significant when compared to CEU, FIN, TSI populations. The A541G allele frequency in the Turkish population showed significantly difference when compared to South East Asian (Thai) and East Asian populations (Japanese, Korean, Han Chinese, Chinese, JPT, $\mathrm{CHB}, \mathrm{KHV}$ ), but no significant difference was observed in comparison to the South Asian populations (Indian, GIH, PJL, STU, ITU). The A541G variant allele frequencies ranged from 31.9 to $45.1 \%$ for South Asian populations. Statistically significant differences were observed between Turkish populations and African populations that include ESN, LWK and ACB except for ASW.

The UGT1A6 c.19T>G allele frequencies in the Turkish population were similar to those in White ancestry that include CEU, FIN, GBR, TSI, CLM and PUR populations, but was found statistically significant higher than those IBS, MXL and PEL populations. The T19G allele frequency in the Turkish population showed significantly difference when compared to some Asian populations that include Thai, Japanese, Korean, Han Chinese, JPT, CHB, KHV and Indian; but was not significantly distinction when compared to the other Asian populations that include GIH, PJL, STU, ITU. In addition, there was no significantly distinction between Turkish and African populations that include ESN, LWK, ACB and ASW. The T19G variant allele frequencies ranged from 34.3 to $42.2 \%$ for African populations.

As seen in Table 2, the frequencies of the UGT1A4 c.142T>G, UGT1A6 c.541A>G and c.19T>G SNPs vary among diverse populations. Differences in the distribution of the frequencies of these alleles may lead to intra- and interpopulation differences in glucuronidation capacity, and this may give rise to inter-ethnic and inter-individual differences in response to drug therapy, therapeutic efficacy, toxicity of drugs and other xenobiotics, susceptibility to diverse diseases. 
Table 2. Comparisons of the frequencies of UGT1A4 c.142T $>\mathrm{G}$ and $U \mathrm{GT1A6}$ c.541A $>\mathrm{G}, \mathrm{c} .19 \mathrm{~T}>\mathrm{G}$ polymorphisms in various population

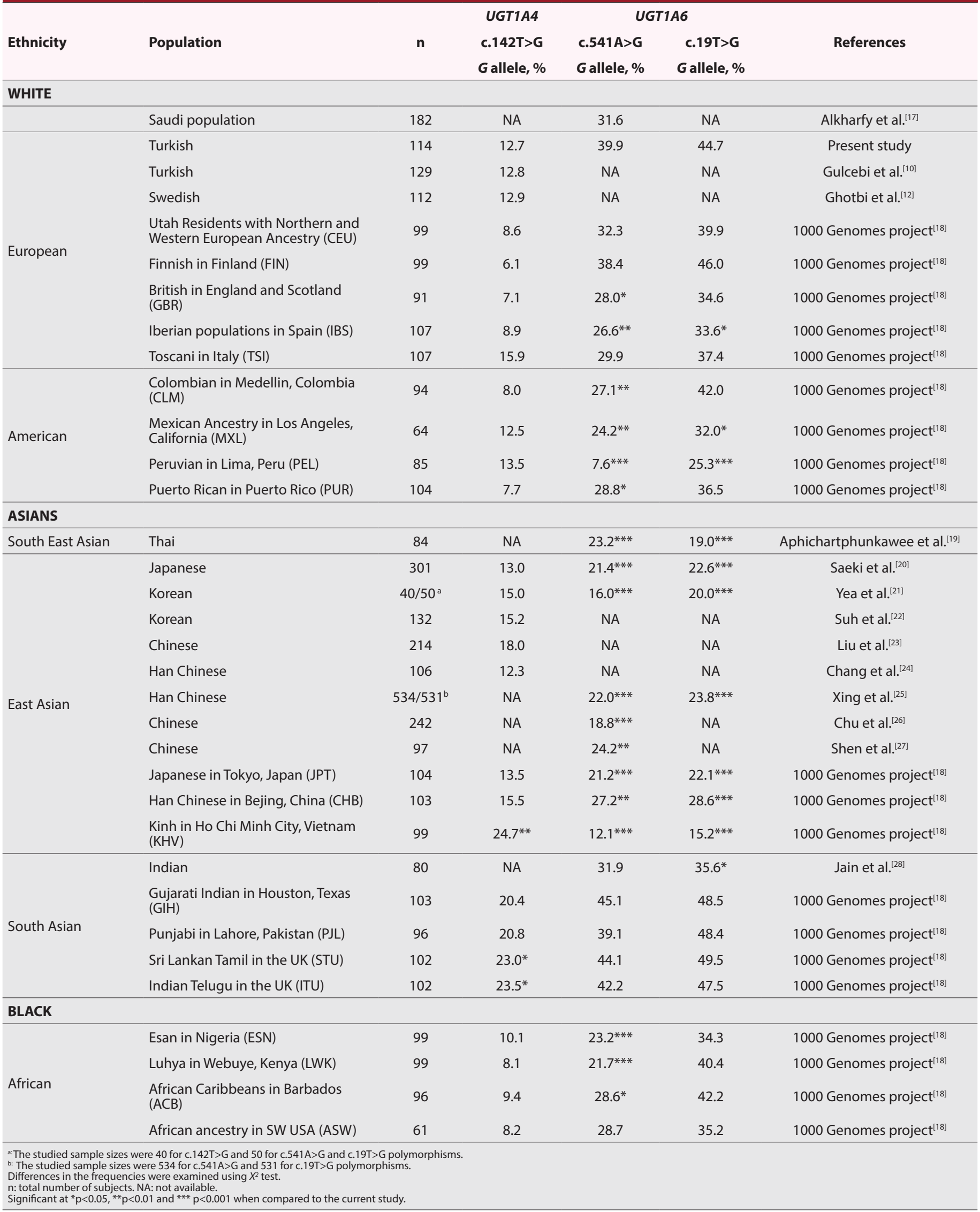


Lamotrigine, which is widely used as an antiepileptic agent in the treatment of epilepsy, is metabolized by UGT enzymes ${ }^{[10]}$, and its main metabolizing enzyme is UGT1A4. ${ }^{[24]}$ Gulcebi et al. ${ }^{[10]}$ reported that L48V polymorphism decreased the serum concentration of lamotrigine in epilepsy patients in the Turkish population who received monotherapy or polytherapy, and that the levels of lamotrigine were importantly lower for smoking or non smoking polymorphic alleles than for normal. In a study by Chang et al. ${ }^{[24]}$ in Han Chinese patients with epilepsy, it was reported that patients with the UGT1A4 142TT polymorphism were observed to have a higher blood lamotrigine concentration and better therapeutic efficacy than those with the 142TG or 142GG genotypes. Du et al. ${ }^{[29]}$ reported that in Chinese children with epilepsy, the TT genotype ofT142G SNP was related to high serum content of lamotrigine and that T142G SNP showed effects on efficacy of lamotrigine. In a study by Ghotbi et al. ${ }^{[12]}$ on Swedish patients with schizophrenia, it was reported that the UGT1A4*3 was related with lower average plasma concentrations of olanzapine.

In a study by Dadheech et al. ${ }^{[13]}$, it was conducted to evaluate the association of UGT1A6 A541G, T19G and A552C SNPs with drug response and adverse drug reactions (ADRs) in $\beta$-thalassemia major patients receiving deferiprone therapy. While a significant difference in the genotypic distribution of the UGT1A6 Thr181Ala polymorphism has been observed in responders and non-responders, no difference was observed in the genotypic distribution between patients with and without ADR. For genotypic distribution of the UGT1A6 T19G polymorphism, there was an important distinction between non-responders with and without ADRs and between responders with and without ADRs. Aphichartphunkawee et al. ${ }^{[19]}$ declared that UGT1A6 541A $>G$ and 552A $>C$ variants were associated with lower valproic acid dose in Thai epileptic patients. Oussallah et al. ${ }^{[30]}$ reported that UGT1A6 A541G, T19G and A552C SNPs were significantly associated with gallstone-related cholecystectomy risk and that the UGT1A6 A541G SNP was related with the highest risk of gallstone-related cholecystectomy (odds ratio=4.58; $95 \%$ confidence interval=1.58-13.28; $p=0.00321$ ). Kua et al. ${ }^{[31]}$ reported that in Chinese individuals, UGT1A6 A541G, T19G and A552C SNPs indicated important relationship with increased lung cancer risk and that UGT1A6 polymorphisms may modify lung cancer risk.

Genetic polymorphisms changing enzyme functions have clinical significance in predicting disease susceptibility and the capability of an individual to respond to particular medications. [32] Genetic polymorphisms could aid individualized drug dosage and improved therapeutics. ${ }^{[33]}$

\section{CONCLUSION}

This study introduces the genetic profiles of UGT1A4 c. $142 T>G, U G T 1 A 6$ c.541A $>G$ and c. $19 T>G$ SNPs in the healthy Turkish population and the comparison of the frequencies obtained with those of various populations. The detection of polymorphisms in the genes encoding the enzymes aforementioned may ensure benefit for dose adjustment of some medications and protection from xenobiotics for precaution and decreasion in adverse drug reactions. This study may help to improve toxicogenetic studies and contribute to epidemiological studies..

\section{ETHICAL DECLARATIONS}

Ethics Committee Approval: The study was approved by Mersin University Ethics Committee (08/07/2020, protocol no: 2020/490).

Informed Consent: The DNA samples used were obtained during the previous study, which was approved by Mersin University Ethics Committee (22/10/2015, protocol no: 2015/317). Informed consent form had been obtained while blood samples were taken from volunteers.

Conflict of Interest Statement: The authors have no conflicts of interest to declare.

Financial Disclosure: The authors declared that this study has received no financial support.

Author Contributions: All of the authors declare that they have all participated in the design, execution, and analysis of the paper, and that they have approved the final version.

\section{REFERENCES}

1. Ge S,Tu Y, Hu M. Challenges and opportunities with predicting in vivo phase II metabolism via glucuronidation from in vitro data. Curr Pharmacol Rep 2016;2(6):326-38.

2. Troberg J, Finel M. The polymorphic variant P24T of UDPglucuronosyltransferase $1 \mathrm{~A} 4$ and its unusual consequences. Drug Metab Dispos 2015;43(11):1769-72.

3. Mehboob H, Tahir IM, Iqbal T, Saleem S, Perveen S, Farooqi A. Effect of UDP-glucuronosyltransferase (UGT) 1A polymorphism (rs8330 and rs10929303) on glucuronidation status of acetaminophen. Dose Response 2017;15(3):1559325817723731.

4. Liu W, Ramírez J, Gamazon ER, et al. Genetic factors affecting gene transcription and catalytic activity of UDP-glucuronosyltransferases in human liver. Hum Mol Genet 2014; 23(20):5558-69.

5. López M, Dorado P, Ortega A, et al. Interethnic differences in UGT1A4 genetic polymorphisms between Mexican Mestizo and Spanish populations. Mol Biol Rep 2013;40(4):3187-92.

6. Reimers A, Sjursen W, Helde G, Brodtkorb E. Frequencies of UGT1A4*2 $(\mathrm{P} 24 \mathrm{~T})$ and $* 3(\mathrm{~L} 48 \mathrm{~V})$ and their effects on serum concentrations of lamotrigine. Eur J Drug Metab Pharmacokinet 2016;41(2):149-55.

7. Meech R, Hu DG, McKinnon RA, et al. The UDP-glycosyltransferase (UGT) superfamily: new members, new functions, and novel paradigms. Physiol Rev 2019;99(2):1153-222.

8. Hanioka N, Iwabu H, Hanafusa H, Nakada S, Narimatsu S. Expression and inducibility of UDP-glucuronosyltransferase 1 As in MCF-7 human breast carcinoma cells. Basic Clin Pharmacol Toxicol 2012;110(3):253-8.

9. Hakooz N, Alzubiedi S, Yousef AM, et al. UDP-glucuronosyltransferase 1 A4 (UGT1A4) polymorphisms in a Jordanian population. Mol Biol Rep 2012;39(7):7763-8.

10. Gulcebi MI, Ozkaynakcı A, Goren MZ, Aker RG, Ozkara C, Onat FY. The relationship between UGT1A4 polymorphism and serum concentration of lamotrigine in patients with epilepsy. Epilepsy Res 2011;95(1-2):1-8.

11. Haslemo T, Loryan I, Ueda N, et al. UGT1A4*3 encodes significantly increased glucuronidation of olanzapine in patients on maintenance treatment and in recombinant systems. Clin Pharmacol Ther 2012;92(2):221-7. 
12. Ghotbi R, Mannheimer B, Aklillu E, et al. Carriers of the UGT1A4 142T>G gene variant are predisposed to reduced olanzapine exposure-an impact similar to male gender or smoking in schizophrenic patients. Eur J Clin Pharmacol 2010;66(5):465-74.

13. Dadheech S, Raoa AV, Shaheen $U$, et al. Three most common nonsynonymous UGT1A6*2 polymorphisms (Thr181Ala, Arg184Ser and Ser7Ala) and therapeutic response to deferiprone in $\beta$-thalassemia major patients. Gene 2013;531(2):301-5.

14. van Oijen MG, Huybers S, Peters WH, et al. Polymorphisms in genes encoding acetylsalicylic acid metabolizing enzymes are unrelated to upper gastrointestinal health in cardiovascular patients on acetylsalicylic acid. Br J Clin Pharmacol 2005;60(6):623-8.

15. Palikhe NS, Kim SH, Nam YH, Ye YM, Park HS. Polymorphisms of aspirinmetabolizing enzymes CYP2C9, NAT2 and UGT1A6 in aspirin-intolerant urticaria. Allergy Asthma Immunol Res 2011;3(4):273-6.

16. Algharably EA, Hamamsy ME, Hassanein SM, et al. The effect of UGT1A6 polymorphism at two loci on the clinical response to valproic acid in epileptic children. Int J Pharm Sci Res 2016;7(10):3986-94.

17. Alkharfy KM, Jan BL, Afzal $S$, et al. Prevalence of UDPglucuronosyltransferase polymorphisms (UGT1A $6 * 2,1 A 7^{*} 12,1 A 8 * 3$, $1 \mathrm{~A} 9 * 3,2 \mathrm{~B} 7^{*} 2$, and $2 \mathrm{~B} 15^{*} 2$ ) in a Saudi population. Saudi Pharm J 2017;25(2):224-30.

18.1000 Genomes Project. https://www.internationalgenome.org/1000genomes-browsers/ (accessed 16.09.2020).

19. Aphichartphunkawee $S$, Chinvarun $Y$, Kijsanayotin P. Association of genetic variants in UGT1A6 genes and non-genetic variant with valproic acid doses and plasma concentration in Thai epileptic patients. Thai J Pharm Sci 2014;38(2):98-105.

20. Saeki M, Saito Y, Jinno H, et al. Haplotype structures of the UGT1A gene complex in a Japanese population. Pharmacogenomics J 2006;6(1):63-75.

21. Yea SS, Lee SS, Kim WY, et al. Genetic variations and haplotypes of UDPglucuronosyltransferase $1 \mathrm{~A}$ locus in a Korean population. Ther Drug Monit 2008;30(1):23-34.

22. Suh HJ, Yoon SH, Yu KS, et al. The Genetic polymorphism UGT1A4*3 is associated with low posaconazole plasma concentrations in hematological malignancy patients receiving the oral suspension. Antimicrob Agents Chemother 2018;62(7):e02230-17.

23. Liu L, Zhao L, Wang Q, Qiu F, Wu X, Ma Y. Influence of valproic acid concentration and polymorphism of UGT1A4*3, UGT2B7 -161C>T and UGT2B7*2 on serum concentration of lamotrigine in Chinese epileptic children. Eur J Clin Pharmacol 2015;71(11):1341-7.

24. Chang Y, Yang LY, Zhang MC, Liu SY. Correlation of the UGT1A4 gene polymorphism with serum concentration and therapeutic efficacy of lamotrigine in Han Chinese of Northern China. Eur J Clin Pharmacol 2014;70(8):941-6.

25. Xing $Y$, Yang L, Wang $L$, et al. Systematic screening for polymorphisms within the UGT1A6 gene in three Chinese populations and function prediction through structural modeling. Pharmacogenomics 2009;10(5):741-52.

26. Chu XM, Zhang LF, Wang GJ, Zhang SN, Zhou JH, Hao HP. Influence of UDP-glucuronosyltransferase polymorphisms on valproic acid pharmacokinetics in Chinese epilepsy patients. Eur J Clin Pharmacol 2012;68(10):1395-401.

27. Shen X, Bi J, Liu Q, et al. Effects of UGT1A3, UGT1A6, and UGT2B7 genetic polymorphisms on plasma concentration of valproic acid in south Chinese epilepsy patients. Int J Clin Exp Pathol 2016;9(4):4513-22.

28. Jain P, Shastri S, Gulati S, et al. Prevalence of UGT1A6 polymorphisms in children with epilepsy on valproate monotherapy. Neurol India 2015;63(1):35-9.

29. Du Z, Jiao Y, Shi L. Association of UGT2B7 and UGT1A4 polymorphisms with serum concentration of antiepileptic drugs in children. Med Sci Monit 2016;22:4107-13.

30. Oussalah A, Bosco P, Anello G, et al. Exome-wide association study identifies new low-frequency and rare UGT1A1 coding variants and UGT1A6 coding variants influencing serum bilirubin in elderly subjects. Medicine (Baltimore) 2015;94(22):e925.

31. Kua LF, Ross S, Lee SC et al. UGT1A6 polymorphisms modulated lung cancer risk in a Chinese population. PLoS One 2012;7(8):e42873.
32. Zhang X, Ao G, Wang $Y$, et al. Genetic variants and haplotypes of the UGT1A9, 1A7 and 1A1 genes in Chinese Han. Genet Mol Biol 2012;35(2):428-34.

33. Uckun Z, Baskak B, Ozdemir H, Ozel-Kizil ET, Devrimci-Ozguven H, Suzen HS. Genotype and allele frequency of CYP3A4-392A $>$ G in Turkish patients with major depressive disorder. Turk J Pharm Sci 2018;15(2):200-6. 